\title{
Knowledge Level On Hiv/Aids: A Case Study On Students Perception And Sexuality Among University Students Community.
}

\author{
Alice A. Anika, Leonard Kiti Alii \\ Educational psychology and Special Needs DepartmentPwani University-P.O.Box 195 Kilifi, Kenya. \\ Physics and Mathematics departmentPwani University-P.O.Box 195 Kilifi, Kenya.
}

\begin{abstract}
Cross sectional survey design was used on this study among university students in Kilifi Kenya. A sample size of 364 was used. Stratified random sampling technique and a questionnaire on Knowledge level on HIV and AIDS was administered. The study revealed knowledge level as $90 \%$. Results on student's sex and sexuality revealed that $5.6 \%$ had multiple sexual partners, $28.9 \%$ had one partner, $93.3 \%$ are in heterosexual relationships, and 6.7\% practiced lesbianism. Sex methods used emerged with heterosexual (90\%) most preferred, oral $\operatorname{sex}(6.6 \%)$ and anal sex $(2.67 \%) .7 \%$ of respondents were alcoholics, $7 \%$ had been raped, $1 \%$ HIV positives.
\end{abstract}

\section{INTRODUCTION}

HIV virus is still a killer disease among the youth (HIV Surveillance Report 2015). In 2015 alone, 670,000 young people between the ages of 15 to 24 were newly infected with HIV, of who 250,000 were adolescents between the ages of 15 and 19 (UNAIDS 2015 Report). About 44\% young adults of between 18- 24 years were reported to be living with the HIV virus but did not know they had HIV (UNICEF Report 2015). However, since 2000, it is reported that about 30 million new infections have been prevented so far worldwide; 8 millions have also been averted while 1.5 million people who are living with HIV are now on treatment (HIV Surveillance Report 2015). No vaccine has been discovered to date. These reports points to the fact that there is need to establish empirical knowledge gap on HIV infection, prevention and treatment methods among institutions of higher learning which is the herb of the young adults life, to mitigate the appropriate prevention strategies. This would help avail data for the student's information data bank, establishment of reliable and valid data, continued research in related areas and for individual, perception, attitude and behavior change. Particular reference to this study focused on current statistics, unveiled data on prevalence, prevention methods, modes of transmission, treatment, general knowledge on HIV and AIDS and challenges affecting the youth today on sex and sexuality. Although, the increased prevalence rate among the adolescents and young adults presumably could be due to generation of children infected with HIV prenatally and who by now have turned to be the young adults. The youth are sexually active during these periods and therefore are exposed to sexual practices, oblivion of further sexual risks with their infected peers. This study was in response to the Kenya Vision 2030, Strategic plan and the call on 2015 New Global HIV strategy which was launched by the International Health with all other partners to end the AIDS epidemic by 2030 among the youths.

\subsection{Survey Objectives}

The key objective of this survey was to obtain a baseline data on student knowledge level on HIV virus and infection prevalence to mitigate for appropriate intervention strategies.

\subsubsection{Specific objectives:}

1. To establish levels of awareness of PU students on HIV and AIDS in terms of;

- Current statistics

- Mode of Transmission and Prevention methods

- Treatment, and

- General knowledge

2. To suggest intervention strategies based on the baseline survey findings

\section{METHODOLOGY}

The study used cross sectional survey research design. This design was suitable for this study because it was possible to cover a range of participants regardless of age difference and generate data required for both 
quantitative and qualitative data analysis. The study was carried out at Pwani University main campus, in KilifiKenya. The student's current enrolment was about 5432. Stratified random sampling procedure was used to sample the students. The sample size was calculated using Krejcie et al, (2002) formula and table for calculating sample size. According to this formula, population above 7000 yield sample size of about 364 . Permission was sort and notification given to the University administration to carry out the survey. The Ethics review Board was consulted for ethics certification. Participants consent was sort before administration of the tool. The questionnaires were administered to the students at various points within the University. Each questionnaire was accompanied with a consent form and a cover letter which explained the purpose of the study. After data collection, the questionnaires were coded and analyzed using both qualitative and quantitative data analysis techniques. The Social Package for Statistics Analysis (SPSS) was used to calculate the results. Participants were assured of anonymity, confidentiality. Dissemination of findings after study completion was also declared as a protocol for the study undertakings.

\subsection{Instrumentation, validity and reliability}

The study used questionnaires to generate data on level of awareness among participants on various aspects of HIV and AIDS. The key issues addressed included knowledge on prevalence rate on HIV and AIDS, transmission, prevention, treatment and general knowledge. The items were 32 in number, with 5 sections. 4 sections out of the 5 sections - carried 5 items while the general questions had 10 items. Two items were open ended questions to solicit opinion on improvement of programme. The items types were triangulated to eliminate ambiguity and achieve reliable scores for validity of results. The items ranged from true/false, strongly agree to strongly disagree, multiple choices and open ended questions. The instruments were subjected to expert scrutiny to establish validity and reliability. Pilot study was conducted first to a certain the validity and reliability of the instrument. The alpha coefficient for the items was 0.728 suggesting that the items had a relatively high internal consistency. From the total population of students of about 5000, 30\% was sampled for pilot as shown in Table 1.2. Hence a sample size of $70 \%$ was used for pilot study.

\subsection{Demographic Characteristics of the Study Sample,}

\section{FINDINGS AND DISCUSSIONS}

\subsubsection{Respondents' Gender}

In terms of gender, the males formed $61.4 \%$ of the total sample size, while the females were $38.6 \%$, Table 4.1

Table 4.1: Respondents' Gender

\begin{tabular}{|l|l|l|l|}
\hline \multicolumn{4}{|c|}{ Gender of Respondent } \\
\hline \multirow{2}{*}{ Valid } & Male & Frequency & Percent, (\%) \\
\cline { 2 - 4 } & Female & 94 & 61.4 \\
\cline { 2 - 4 } & Total & 59 & 38.6 \\
\hline
\end{tabular}

The gender representation is in line with the PU students' gender balance. The males form two thirds of the student population while the females form one third.

\subsubsection{Age of Respondents}

Majority of the students interviewed were within the age bracket of 17-30, Table 4.2. According to the education system in Kenya, this age bracket is in line with the expectations as per the 8.4.4 system of education. This is also because the students interviewed were on a regular programme as opposed to institutional based programmes which include mature students some of whom are parents or already employed.

Table 4.2: Age of Respondents

\begin{tabular}{|l|l|l|l|l|}
\hline \multicolumn{5}{|c|}{ Age of Respondent } \\
\hline \multirow{3}{*}{ Valid } & & Frequency & Percent, (\%) & \\
& $17-25$ & 138 & 90.2 & \\
\cline { 2 - 6 } & $26-30$ & 9 & 5.9 & \\
\hline & Total & 147 & 96.1 & \\
\hline
\end{tabular}

\subsubsection{Year of Study of Respondents}

The respondents' year of study was quite representative. The largest group of students at PU were the undergraduates, followed by Diploma, Certificate then Masters. The sample therefore showed clear representation. Table, 4.3 
Table 4.3: Age of Respondents

\begin{tabular}{|l|l|l|l|}
\hline \multicolumn{2}{|l|}{} & Year of Study \\
\hline \multirow{4}{*}{ Valid } & Frequency & Percent, (\%) \\
\cline { 2 - 4 } & Certificate & 6 & 3.9 \\
\cline { 2 - 4 } & Diploma & 25 & 16.3 \\
\cline { 2 - 4 } & Undergraduate & 106 & 69.3 \\
\cline { 2 - 4 } & Post Graduate & 13 & 8.5 \\
\cline { 2 - 4 } & Total & 150 & 98.0 \\
\hline
\end{tabular}

\subsubsection{School of Respondents}

All the schools were well represented. School of Education had the largest number of students, followed by School of Humanities, School of Pure and Applied Sciences,(SPAS), School of Agricultural and Environmental Sciences, (SEAS) and, School of Health Sciences, (SHS), in that order - Table 4.4

Table 4.4: School Respondents

\begin{tabular}{|l|l|l|l|}
\hline \multicolumn{2}{|c|}{} & School respondent \\
\hline \multirow{3}{*}{ Valid } & Education & Frequency & Percent \\
\cline { 2 - 4 } & Humanities and Social Sciences & 67 & 43.8 \\
\cline { 2 - 4 } & Pure and Applied Sciences & 30 & 19.6 \\
\cline { 2 - 4 } & Agricultural and Environmental Studies & 27 & 17.6 \\
\cline { 2 - 4 } & Health Sciences & 18 & 11.8 \\
\cline { 2 - 4 } & Total & 11 & 7.2 \\
\hline
\end{tabular}

\subsubsection{Students Relationships, Type and Preferred Methods of Sexual Encounters}

Majority of students had no sexual partners, $(65 \%)$. The second largest groups were those with one partner, $(28.9 \%)$, followed by those with multiple partners at $5.6 \%$. It is important to note that the percentage of those with sexual partners, whether one or many is quite significant. This indicates that as young adults, this is the time they require close guidance and continuous counseling so as to adopt healthy lifestyles, Table 4.5, 4.6 and 4.7

Table 4.5: Student Relationships

\begin{tabular}{|l|l|l|l|l|l|}
\hline \multicolumn{5}{|c|}{ Relationships } \\
\hline \multirow{3}{*}{ Valid } & Frequency & Percent & $95 \%$ Confidence Interval \\
\cline { 2 - 6 } & No sexual partner & 93 & 65.5 & 64.83 & 66.15 \\
\cline { 2 - 6 } & One partner & 41 & 28.9 & & \\
\cline { 2 - 6 } & Multiple sexual partners & 8 & 5.6 & & \\
\cline { 2 - 6 } & Total & 142 & 92.8 & & \\
\hline
\end{tabular}

The types of relationships students engage in include lesbianism and heterosexual behaviors. Majority of the students, (93.3\%) who are sexually active engage in heterosexual behavior. This is in line with the Kenya cultural values where other sexual encounters such as lesbianism and homosexuality are not embraced or encouraged and not accepted by most communities in Africa, Table 4.6

Table 4.6: Types of Relationships

\begin{tabular}{|l|l|l|l|l|l|}
\hline \multicolumn{5}{|c|}{ If in a sexual relationship, what type } \\
\hline \multicolumn{3}{|c|}{} & Frequency & Percent, $(\%)$ & $95 \%$ Confidence Interval \\
\hline \multirow{3}{*}{ Valid } & Heterosexual & 70 & 93.3 & 92.68 & 93.98 \\
\cline { 2 - 6 } & Lesbianism & 5 & 6.7 & & \\
\cline { 2 - 6 } & Total & 75 & 49.0 & & \\
\hline
\end{tabular}

The survey observed that students practice oral, anal and heterosexual methods of sexual activities. Majority of students practice, heterosexual, followed by oral and lastly anal sexual patterns. This is an important revelation in the fight against HIV/AIDS scourge. Awareness creation related to these various sexual encounters identified is necessary, Table 4.7

Table 4.7: Sex Methods Preferred 


\begin{tabular}{|c|c|c|c|c|c|}
\hline \multicolumn{6}{|c|}{ If Sexually active, what sex method do you prefer? } \\
\hline \multirow{5}{*}{ Valid } & \multirow[b]{2}{*}{ Oral } & \multirow{2}{*}{$\begin{array}{l}\text { Frequency } \\
5 \\
\end{array}$} & \multirow{2}{*}{$\begin{array}{l}\text { Percent } \\
6.67 \\
\end{array}$} & \multicolumn{2}{|c|}{$95 \%$ Confidence Interval } \\
\hline & & & & & \\
\hline & Anal & 2 & 2.677 & & \\
\hline & Heterosexual & 66 & 90.41 & 89.62 & 91.2 \\
\hline & Total & 73 & 47.7 & & \\
\hline
\end{tabular}

\subsection{Health Status \\ i) General Health Status}

The health status of respondents indicates that students experience different health related problems. These include STI, 1\%; HIV+ 1\%, Drug addiction 1\%, and Alcoholism, 7\%. 11\% of the respondents have suffered rape, while among the female gender $42 \%$ are currently not pregnant. The statistics reveal a wide array of relationship and sex related issues that cut across the board. The statistics therefore point towards the realization that there is need for an all-round, holistic way of managing behavior related issues among the students, Table 4.8

Table 4.8: Current Health Status

\begin{tabular}{|c|c|c|c|c|c|}
\hline \multicolumn{6}{|c|}{ Current Health Status } \\
\hline & & Frequency & Percent & $95 \% \mathrm{C}$ & ce Interval \\
\hline \multirow[t]{9}{*}{ Valid } & Pregnant & 1 & 1 & & \\
\hline & $\mathrm{HIV}+$ & 1 & 1 & & \\
\hline & STI infected & 1 & 1 & & \\
\hline & Drug addicted & 1 & 1 & & \\
\hline & Not pregnant & 42 & 42.00 & 41.03 & 44.43 \\
\hline & Alcoholic & 7 & 7 & & \\
\hline & Recently Raped & 11 & 11 & & \\
\hline & Others & 36 & 36 & & \\
\hline & Total & 100 & 65.4 & & \\
\hline
\end{tabular}

\section{ii) Pregnancy}

$50 \%$ of the respondents who were pregnant were willing to carry the pregnancy to full term. The other $50 \%$ were not ready for the same task. This implied that some of the pregnancies were not planned and therefore involved unprotected sex without taking into consideration the responsibility or risks associated with unprotected sex. This situation also calls for more education on family planning options, (Table 4.9)

Table 4.9: Pregnancy

\begin{tabular}{|l|l|l|l|l|l|}
\hline \multicolumn{5}{|c|}{ If pregnant do you want to carry it to full term? } \\
\hline \multicolumn{3}{|c|}{} & Frequency & Percent, $(\%)$ & $95 \%$ Confidence Interval \\
\hline \multirow{3}{*}{ Valid } & Yes & 2 & 50.0 & 25.5 & 74.5 \\
\cline { 2 - 7 } & No & 2 & 50.0 & & \\
\cline { 2 - 6 } & Total & 4 & 100.0 & & \\
\hline
\end{tabular}

\section{iii) Condom Use and Awareness of other Protective Methods}

Condom use among students is varied. $83 \%$ of respondents know how to use condoms, $13 \%$ do not. $57 \%$ use condoms all the time, $21 \%$ most of the time, $11 \%$ rarely and $12 \%$ never. About $20 \%$ of the students do not or rarely use condoms. This is a worrying trend because it is a significant figure in HIV infection. Behavior change communication encourages consistency of protection use. The respondents indicated that the inability to use condoms always is associated with alcohol, lack of awareness and inadequate condoms in the dispensers, Table 4.10, 4.11 and 4.12

Table 4.10: Use of Condoms

\begin{tabular}{|l|l|l|l|l|l|}
\hline \multicolumn{5}{|c|}{ Do you use (condom) protection during Sex? } \\
\hline \multicolumn{2}{|c|}{} & Frequency & Percent, (\%) & $95 \%$ Confidence Interval \\
\hline Valid & Yes all the time & 59 & 57.3 & 56.36 & 58.24 \\
\hline
\end{tabular}


Knowledge Level On Hiv/Aids: A Case Study On Students Perception And

\begin{tabular}{|l|l|l|l|l|l|}
\hline \multirow{7}{*}{} & Most of the time & 21 & 20.3 & & \\
\cline { 2 - 6 } & Rarely & 11 & 10.7 & & \\
\cline { 2 - 6 } & Never & 12 & 11.7 & & \\
\cline { 2 - 6 } & Total & 103 & & & \\
\hline Total & 153 & & & \\
\hline
\end{tabular}

The results revealed that the respondents were quite informed on sexual protective methods. Table $4.11,73.1 \%$ are aware of sex protective methods. The percentage of those not aware was low, 6.2\%. This implied that students are responsible in their sexual interactions and behaviors.

Table 4.11: Reasons for not Using Condoms

\begin{tabular}{|l|l|l|l|l|l|}
\hline \multicolumn{2}{|c|}{ If no what is the reason } \\
\hline \multirow{5}{*}{ Valid } & Frequency & Percent & 95\% Confidence Interval \\
& $\begin{array}{l}\text { Under The Influence of } \\
\text { Alcohol And Drugs }\end{array}$ & 6 & 26.1 & & \\
\cline { 2 - 6 } & Lack of Information & 2 & 8.7 & & \\
\cline { 2 - 6 } & Empty Dispensers & 11 & 47.8 & 43.54 & 52.06 \\
\cline { 2 - 6 } & Others (Specify) & 3 & 13.0 & & \\
\cline { 2 - 6 } & 5 & 1 & 4.3 & & \\
\cline { 2 - 6 } & Total & 23 & 100.0 & & \\
\hline
\end{tabular}

Table 4.12 Awareness of Sex Preventive Methods

\begin{tabular}{|c|c|c|c|c|c|}
\hline \multicolumn{6}{|c|}{ Am well aware of sex protective methods } \\
\hline & & Frequency & $\begin{array}{l}\text { Percent } \\
(\%)\end{array}$ & $\begin{array}{l}95 \% \\
\text { Inter }\end{array}$ & nfidence \\
\hline \multirow[t]{6}{*}{ Valid } & Not at all characteristic of me & 9 & 6.2 & & \\
\hline & Slightly characteristic of me & 16 & 11.0 & & \\
\hline & Somewhat characteristic of me & 8 & 5.5 & & \\
\hline & Moderately characteristic of me & 6 & 4.1 & & \\
\hline & Very characteristic of me & 106 & 73.1 & 7250 & 73.70 \\
\hline & Total & 145 & 100.0 & & \\
\hline
\end{tabular}

iv) Sex and Marriage

Respondents had different views on sexual encounters. Majority, (63\%) were willing to wait or delay sexual encounters till they get married. The percentage of students not willing to delay their sexual encounters $37 \%$ was also significant. Table 4.13

Table 4. 13: Sex and Marriage

\begin{tabular}{|c|c|c|c|c|c|}
\hline \multicolumn{6}{|c|}{ I want to have sex after marriage } \\
\hline & & Frequency & \multirow{2}{*}{$\begin{array}{l}\text { Percent } \\
26.9 \\
\end{array}$} & \multicolumn{2}{|c|}{$\begin{array}{l}\text { 95\% Confidence } \\
\text { Interval }\end{array}$} \\
\hline \multirow[t]{6}{*}{ Valid } & Not at all characteristic of me & 39 & & & \\
\hline & Slightly characteristic of me & 7 & 4.8 & & \\
\hline & Somewhat characteristic of me & 15 & 10.3 & & \\
\hline & Moderately characteristic of me & 21 & 14.5 & & \\
\hline & Very characteristic of me & 63 & 43.4 & 42.73 & 44.07 \\
\hline & Total & 145 & 100.0 & & \\
\hline
\end{tabular}

$76 \%$ of the respondents also indicated that they are aware of their sexuality. This is quite encouraging as it translates to one being able to make decision with regard to sexuality and responsible behavior, Table 4.14

Table 4.14: Responsible Sexual Behavior My sexuality is something that I am largely responsible for 


\begin{tabular}{|l|l|l|l|l|l|}
\hline \multicolumn{2}{|c|}{} & Frequency & $\begin{array}{l}\text { Percent, } \\
(\%)\end{array}$ & $\begin{array}{l}\text { 95\% Confidence } \\
\text { Interval }\end{array}$ \\
\hline \multirow{7}{*}{ Valid } & Not at all characteristic of me & 9 & 6.3 & & \\
\cline { 2 - 6 } & Slightly characteristic of me & 9 & 6.3 & & \\
\cline { 2 - 6 } & Somewhat characteristic of me & 6 & 4.2 & & \\
\cline { 2 - 6 } & Moderately characteristic of me & 10 & 7.0 & & 76.69 \\
\cline { 2 - 6 } & Very characteristic of me & 108 & 76.1 & 75.51 & \\
\cline { 2 - 6 } & Total & 142 & 100.0 & & \\
\hline
\end{tabular}

It was also observed that participants are aware of their sexual feelings, $(70.6 \%)$. Small percentage still does not understand their sexual feelings and should be targeted for further education and awareness creation, Table 4.15

Table 4.15: Awareness of Sexual Feelings

\begin{tabular}{|l|l|l|l|l|l|}
\hline \multicolumn{2}{|l|}{ I am very aware of my sexual feelings } & Frequency & $\begin{array}{l}\text { Percent } \\
(\%)\end{array}$ & $\begin{array}{l}\text { 95\% Confidence } \\
\text { Interval }\end{array}$ \\
\hline \multirow{4}{*}{ Valid } & Not at all characteristic of me & 9 & 6.3 & & \\
\cline { 2 - 6 } & Slightly characteristic of me & 12 & 8.4 & & \\
\cline { 2 - 6 } & Somewhat characteristic of me & 11 & 7.7 & & \\
\cline { 2 - 6 } & Moderately characteristic of me & 10 & 7.0 & & \\
\cline { 2 - 6 } & Very characteristic of me & 101 & 70.6 & 69.98 & 71.22 \\
\cline { 2 - 6 } & Total & 143 & 100.0 & & \\
\hline
\end{tabular}

\section{(v) Other Sex Related Aspects}

Other aspects of sex related prevention results included, 59.9\% knew how to prevent STIs. 31\% do not feel anxious when they think of sexual engagement, while $25 \%$ are quite comfortable with these encounters. $53 \%$ are assertive about their sexuality, $51.8 \%$ are depressed about sex without protection, while $18 \%$ are not bothered. $44 \%$ of the respondents are of the opinion that sex is not necessary while still in school, while $31 \%$ feel that there is nothing wrong with sex while still in school.

\subsubsection{Global and National Issue Related to HIV/AIDS}

This section tested the level of students' awareness on global and national issues related to HIV/AIDS. Majority of the respondents indicated that globally, the number of HIV infected people is more than One Million. They are also aware that the number of HIV infected people in Kenya is more than One Million, Table 4.14 and Table 4.15. The awareness level on the percentage of women in Kenya infected with HIV virus is also in line with general knowledge about the same situation, Table 4.16

Table 4.14: Awareness on HIV/AIDS Prevalence at Global Level

\begin{tabular}{|l|l|l|l|l|l|}
\hline \multicolumn{5}{|c|}{ Globally the Number of HIV infected People are more than 1 M } \\
\hline \multirow{2}{*}{ Valid } & Frequency & Percent & $95 \%$ Confidence Interval \\
\cline { 2 - 6 } & True & 125 & 83.3 & 82.81 & 83.79 \\
\cline { 2 - 6 } & False & 25 & 16.7 & & \\
\cline { 2 - 6 } & Total & 150 & 100.0 & & \\
\hline
\end{tabular}

Table 4.14: Awareness on HIV/AIDS Prevalence in Kenya

\begin{tabular}{|c|c|c|c|c|c|}
\hline \multicolumn{6}{|c|}{ Number of HIV People in Kenya are 500,000} \\
\hline & & Frequency & Percent & $95 \% \mathrm{C}$ & rval \\
\hline \multirow[t]{3}{*}{ Valid } & True & 61 & 41.5 & & \\
\hline & False & 86 & 58.5 & 57.84 & 59.16 \\
\hline & Total & 147 & 100.0 & & \\
\hline
\end{tabular}

Table 4.15: Number of Women with HIV Virus in Kenya

\begin{tabular}{|l|l|l|l|l|l|}
\hline \multicolumn{5}{|c|}{ Number of Women with HIV in Kenya is below 10\% } \\
\hline \multirow{2}{*}{ Valid } & True & Frequency & Percent & 95\% Confidence Interval \\
\cline { 2 - 6 } & False & 15 & 10.1 & & 90.3 \\
\cline { 2 - 6 } & Total & 133 & 89.9 & 89.50 & \\
\hline
\end{tabular}


The respondents are aware of the prevalence of HIV/AIDS in Kenya. HIV/AIDS prevalence is not lowest in the Rift Valley region as the statement tried to affirm, Table 4.16. There is general agreement that HIV/AIDS has increased among married couples in Kenya. $74.7 \%$ supported this statement, Table 4.17. A small percentage of students are still not knowledgeable about the HIV/AIDS prevalence in Kenya as per the previous provinces. $25 \%$ of the respondents do not know that HIV infection has increased among the married couples. This is a matter of great concern as there is an increasing trend among young girls to have relationships with married men they refer to as 'sponsors'

Table 4.16: Lowest HIV Prevalence in Kenya is Rift valley

\begin{tabular}{|l|l|l|l|l|l|}
\hline \multicolumn{6}{|c|}{ Lowest HIV Prevalence in Kenya is Rift valley } \\
\hline \multirow{3}{*}{ Valid } & True & Frequency & Percent & $95 \%$ Confidence Interval \\
\cline { 2 - 6 } & False & 52 & 35.9 & & \\
\cline { 2 - 7 } & Total & 93 & 64.1 & 63.45 & 64.75 \\
\hline
\end{tabular}

\subsubsection{HIV Virus Prevention and Transmission}

Abstinence was accepted as the best and surest way of avoiding HIV virus. This was supported by $68 \%$ of the respondents. However, there is still $15 \%$ of the respondents who are of the contrary opinion, and $3 \%$ who are not aware at all, Table 4.17. There was also strong disagreement that antibiotics can prevent the infection by HIV virus, Table 4.18. $60 \%$ of the respondents also disagreed with the statement that using two condoms can help reduce the spread of HIV Virus. On the other hand, $34 \%$ of responded did not support the statement that deep kissing can cause the spread of the Virus. On whether antibiotics can help in reducing the spread of HIV Virus, 55\% supported this statement indicating that the level of awareness on HIVAIDS and the use of antibiotics are low.

Table 4.17: Abstinence

\begin{tabular}{|l|l|l|l|l|l|}
\hline \multicolumn{6}{|c|}{ Abstinence is the only surest way of avoiding HIV } \\
\hline \multirow{4}{*}{ Valid } & Strongly Disagree & 23 & 15.1 & $95 \%$ Confidence Interval \\
\cline { 2 - 6 } & Disagree & 21 & 13.8 & & \\
\cline { 2 - 6 } & Don't Know & 5 & 3.3 & & \\
\cline { 2 - 6 } & Agree & 30 & 19.7 & & \\
\cline { 2 - 6 } & Strongly Agree & 73 & 48.0 & 47.36 & 48.64 \\
\cline { 2 - 6 } & Total & 152 & 100.0 & & \\
\hline
\end{tabular}

Table 4.18: Use of Antibiotics

\begin{tabular}{|l|l|l|l|l|l|}
\hline \multicolumn{6}{|c|}{ Use of antibiotic can prevent one from acquiring HIV } \\
\hline \multirow{4}{*}{ Valid } & Frequency & Percent & $95 \%$ Confidence Interval \\
\cline { 2 - 6 } & Strongly Disagree & 83 & 55.3 & 54.65 & 55.95 \\
\cline { 2 - 6 } & Disagree & 45 & 30.0 & & \\
\cline { 2 - 6 } & Don't Know & 15 & 10.0 & & \\
\cline { 2 - 6 } & Agree & 3 & 2.0 & & \\
\cline { 2 - 6 } & Strongly Agree & 3 & 2.0 & & \\
\cline { 2 - 6 } & Total & 150 & 100.0 & & \\
\hline
\end{tabular}

The respondents were further presented with statements testing their knowledge on transmission of HIV Virus. On whether all pregnant women infected with HIV can have HIV+ babies, the responses revealed that this is not always the case. $45 \%$ strongly disagreed with this statement and $40 \%$ disagreed. As per the general knowledge of mother to child prevention, the transmission can be minimized based on the care given during delivery and when breastfeeding, Table 4.19. Equally, there was a high percentage of respondents, who strongly disagreed and disagreed with the statement that passing urine immediately after sexual contact can prevent HIV virus transmission, Table 4.20

\begin{tabular}{|l|l|l|l|l|l|}
\hline \multicolumn{5}{|c|}{ Table 4.19: All pregnant women infected with HIV can have HIV+ babies } \\
\hline \multicolumn{2}{|c|}{} & Frequency & Percent & $95 \%$ Confidence Interval \\
\hline Valid & Strongly Disagree & 69 & 45.4 & 44.76 & 46.04 \\
\hline
\end{tabular}


Knowledge Level On Hiv/Aids: A Case Study On Students Perception And

\begin{tabular}{|l|l|l|l|l|l|}
\hline \multirow{7}{*}{} & Disagree & 61 & 40.1 & & \\
\cline { 2 - 6 } & Don't Know & 3 & 2.0 & & \\
\cline { 2 - 6 } & Agree & 15 & 9.9 & & \\
\cline { 2 - 6 } & Strongly Agree & 4 & 2.6 & & \\
\cline { 2 - 6 } & Total & 152 & 100.0 & & \\
\hline
\end{tabular}

\begin{tabular}{|l|l|l|l|l|l|}
\hline \multicolumn{2}{|c|}{ Table 4.20: Passing Urine immediately after sexual contact can prevent HIV } \\
\hline \multicolumn{3}{|c|}{ Valid } & Frequency & Percent (\%) & $95 \%$ Confidence Interval \\
\cline { 2 - 6 } & Strongly Disagree & 74 & 49.3 & 48.65 & 49.95 \\
\cline { 2 - 6 } & Disagree & 54 & 36.0 & & \\
\cline { 2 - 6 } & Don't Know & 15 & 10.0 & & \\
\cline { 2 - 6 } & Agree & 5 & 3.3 & & \\
\cline { 2 - 6 } & Strongly Agree & 2 & 1.3 & & \\
\cline { 2 - 6 } & Total & 150 & 100.0 & & \\
\hline
\end{tabular}

It was also observed that the respondents were aware that anal sex could transmit HIV Virus. This has come out clearly on Table 4.21 where $57.6 \%$ strongly disagreed and $25.8 \%$ disagreed with the statement that anal sex cannot transmit HIV.

\begin{tabular}{|l|l|l|l|l|l|}
\hline \multicolumn{5}{|c|}{ Table 4.21: Having Anal sex cannot transmit HIV virus } \\
\hline \multirow{4}{*}{ Valid } & Strongly Disagree & 87 & Percent & 95\% Confidence Interval \\
\cline { 2 - 6 } & Disagree & 39 & 57.6 & 56.96 & 58.24 \\
\cline { 2 - 6 } & Don't Know & 16 & 25.8 & & \\
\cline { 2 - 6 } & Agree & 5 & 10.6 & & \\
\cline { 2 - 6 } & Strongly Agree & 4 & 3.3 & & \\
\cline { 2 - 6 } & Total & 151 & 2.6 & & \\
\hline
\end{tabular}

The respondents were also presented with the statement that a woman cannot get HIV virus if she has sex during her menses. The responses are given on Table 4.22. 58.3\% of the respondents strongly disagreed with this statement, $29.3 \%$ disagreed, while 5\% agreed. There is a small percentage, $13 \%$ who did not have any idea. This means that the respondents are aware that the HIV virus can be transmitted as long as where there is no protection during sexual contact

\begin{tabular}{|c|c|c|c|c|c|}
\hline \multicolumn{6}{|c|}{ Table 4.22: A women cannot get HIV if she has sex during her menses } \\
\hline & & Frequency & Percent & $\begin{array}{l}95 \% \\
\text { Interv }\end{array}$ & nce \\
\hline \multirow[t]{6}{*}{ Valid } & Strongly Disagree & 88 & 58.3 & 57.66 & 58.94 \\
\hline & Disagree & 45 & 29.8 & & \\
\hline & Don't Know & 13 & 8.6 & & \\
\hline & Agree & 2 & 1.3 & & \\
\hline & Strongly Agree & 3 & 2.0 & & \\
\hline & Total & 151 & 100.0 & & \\
\hline
\end{tabular}

The question on whether coughing and sneezing cannot spread HIV virus also attracted mixed reactions. $46.7 \%$ strongly agreed that this is the case; $25.7 \%$ agreed; $14 \%$ strongly disagreed and $9.9 \%$ disagreed and $3 \%$ had no idea about this matter, Table 4.23. The results show that there is need for more awareness campaigns as there was no clear win on either side.

\begin{tabular}{|l|l|l|l|l|l|}
\hline \multicolumn{6}{|c|}{ Table 4.23: Coughing and Sneezing do not spread HIV } \\
\hline \multirow{7}{*}{ Valid } & Strongly Disagree & Frequency & Percent & 95\% Confidence Interval \\
\cline { 2 - 6 } & Disagree & 22 & 14.5 & & \\
\cline { 2 - 6 } & Don't Know & 15 & 9.9 & & \\
\cline { 2 - 6 } & Agree & 5 & 3.3 & & \\
\cline { 2 - 6 } & Strongly Agree & 39 & 25.7 & 46.06 & 47.34 \\
\cline { 2 - 6 } & Total & 71 & 46.7 & & \\
\hline
\end{tabular}




\subsection{General Knowledge Questions}

In handling HIV/AIDS patients, the respondents were of the opinion that it necessary to take precautions, that is wear gloves, Table 4.24. This proves that the respondents are aware of the safety precautions related to HIV/AIDS

\begin{tabular}{|l|l|l|l|l|l|}
\hline \multicolumn{2}{|c|}{ Table 4.24: Which of the following is a must while handling an Aids Patient with sores } \\
\hline \multicolumn{2}{|c|}{} & Frequency & Percent & \multicolumn{2}{|c|}{$\begin{array}{l}\text { 95\% Confidence } \\
\text { Interval }\end{array}$} \\
\hline \multirow{7}{*}{ Valid } & Wear gloves when birthing them & 135 & 91.8 & 91.43 & 92.17 \\
\cline { 2 - 7 } & $\begin{array}{l}\text { Throw away cups and Plates after } \\
\text { feeding }\end{array}$ & 7 & 4.8 & & \\
\cline { 2 - 7 } & Don't touch them & 5 & 3.4 & & \\
\cline { 2 - 7 } & Total & 147 & 100.0 & & \\
\hline
\end{tabular}

There was mixed responses on the symptoms of HIV/AIDS especially in stage three. $38.5 \%$ selected coughing and zoster, $23.7 \%$ selected Herpes Zoster, while 37.8\% selected generalized lymphadenopathy. There was no clear general agreement on the stage three symptoms of HIV/AIDS. This requires further work, Table 4.24

\begin{tabular}{|l|l|l|l|l|l|}
\hline \multicolumn{5}{|c|}{ Table 4.24: Which symptom is most likely to occur in stage three } \\
\hline \multirow{3}{*}{ Valid } & Herpes Zoster & Frequency & Percent & 95\% Confidence Interval \\
\cline { 2 - 6 } & Coughing and zoster & 32 & 23.7 & & \\
\cline { 2 - 6 } & Generalized lymphadenopathy & 52 & 38.5 & 37.79 & 39.21 \\
\cline { 2 - 6 } & Total & 51 & 37.8 & & \\
\hline
\end{tabular}

Other general questions testing facts about HIV/AIDS also attracted varying responses. As given in Table 4.25. $85 \%$ of the respondents observed that eating from the same plate with HIV + people is not necessarily a path through which the HIV virus is transmitter

\begin{tabular}{|l|l|l|l|l|l|}
\hline \multicolumn{9}{|c|}{ Table 4.25: Which is not true about HIV treatment } \\
\hline \multicolumn{1}{|c|}{} & Frequency & Percent & \multicolumn{2}{l|}{$\begin{array}{l}\text { 95\% Confidence } \\
\text { Interval }\end{array}$} \\
\hline \multirow{7}{*}{ Valid } & There is no cure for HIV & 12 & 8.2 & & \\
\cline { 2 - 6 } & $\begin{array}{l}\text { Eating from the same plate with an infected } \\
\text { person gives HIV }\end{array}$ & 126 & 85.7 & 85.23 & 86.17 \\
\cline { 2 - 7 } & HIV weakens you body Immunity & 6 & 4.1 & & \\
\cline { 2 - 7 } & $\begin{array}{l}\text { An infected person may look and feel okay for } \\
\text { years }\end{array}$ & 3 & 2.0 & & \\
\cline { 2 - 7 } & Total & 147 & 100.0 & & \\
\hline
\end{tabular}

The respondents were able to relate HIV to AIDS. 73.6\% were able to identify the false statement that AIDS causes HIV. This statement is not correct as it a general knowledge that HIV causes AIDS, Table 4.2

\begin{tabular}{|l|l|l|l|l|l|}
\hline \multicolumn{9}{|c|}{ Table 4.26: Which is not correct about HIV } \\
\hline \multicolumn{2}{|c|}{} & Frequency & Percent & \multicolumn{2}{l|}{$\begin{array}{l}\text { 95\% Confidence } \\
\text { Interval }\end{array}$} \\
\hline \multirow{2}{|c|}{$\begin{array}{l}\text { An infected couple can give birth to a healthy } \\
\text { infant }\end{array}$} & 5 & 3.6 & & \\
\cline { 2 - 6 } & AIDS causes HIV & 103 & 73.6 & 72.98 & 74.22 \\
\cline { 2 - 6 } & Baby can be infected through breastfeeding & 15 & 10.7 & & \\
\cline { 2 - 6 } & Mosquito bites cannot cause HIV infection & 17 & 12.1 & & \\
\cline { 2 - 6 } & Total & 140 & 100.0 & & \\
\hline
\end{tabular}

The respondents correctly stated that a person with the HIV virus develops AIDS when the CD4 Count is below 200, (Table 4.27)

\begin{tabular}{|c|c|c|c|}
\hline Table 4.27: When does a perso & n with HIV is & fection $h$ & IDS \\
\hline & Frequency & Percent & $95 \%$ Confidence \\
\hline
\end{tabular}


Knowledge Level On Hiv/Aids: A Case Study On Students Perception And

\begin{tabular}{|l|l|l|l|l|l|}
\hline \multicolumn{3}{|c|}{ Valid } & When CD4 count is below 200 & 88 & \multicolumn{3}{l|}{ Interval } \\
\cline { 2 - 6 } & When CD4 count is 400 & 13 & 73.9 & 73.18 & 74.62 \\
\cline { 2 - 6 } & When CD4 count is at 1000 & 7 & 10.9 & & \\
\cline { 2 - 6 } & When CD4 count is 500 & 11 & 9.9 & & \\
\cline { 2 - 6 } & Total & 119 & 100.0 & & \\
\hline
\end{tabular}

There was general understanding that it is not always the case that among HIV+ couples, the person who dies first is the one who brought the disease. $90.6 \%$ of the respondents disagreed with this statement, $79.7 \%$ also responded that it is not always the case that orphans who had HIV+ parents are most likely to die, Tables 4.28 and 4.29

\begin{tabular}{|c|l|l|l|l|l|}
\hline \multicolumn{6}{|c|}{ Table 4.28: One who dies first is the one who brought it } \\
\hline \multicolumn{3}{|c|}{} & Frequency & Percent & $95 \%$ Confidence Interval \\
\hline \multirow{3}{*}{ Valid } & True & 13 & 8.7 & & \\
\cline { 2 - 6 } & False & 135 & 90.6 & 90.22 & 90.98 \\
\cline { 2 - 6 } & Total & 149 & 100.0 & & \\
\hline
\end{tabular}

\begin{tabular}{|l|l|l|l|l|l|}
\hline \multicolumn{6}{|c|}{ Table 4.29: Orphans with dead parents are most likely to get HIV } \\
\hline \multicolumn{3}{|c|}{ Valid } & Frequency & Percent (\%) & $95 \%$ Confidence Interval \\
\cline { 2 - 6 } & True & 30 & 20.3 & & \\
\cline { 2 - 6 } & Totse & 118 & 79.7 & 79.17 & 80.23 \\
\hline
\end{tabular}

High level of awareness was also observed in relation to HIV/AIDS and STIs. $78.1 \%$ of the respondents indicated that sexually transmitted disease can predispose one into getting HIV virus, Table 4.30. About 88.7 of those interviewed did not support the statement that there is no need in spending a lot of money on HIV programs since there is no cure anyway, Table 4.31

\begin{tabular}{|l|l|l|l|l|l|}
\hline \multicolumn{3}{|c|}{ Table 4.30: Sexually transmitted infections can predispose one into getting HIV } \\
\hline \multicolumn{2}{|c|}{} & $\begin{array}{l}\text { Frequenc } \\
\text { y }\end{array}$ & $\begin{array}{l}\text { Perce } \\
\text { nt }\end{array}$ & \multicolumn{2}{l|}{$95 \%$ Confidence Interval } \\
\hline \multirow{3}{*}{ Valid } & True & 114 & 78.1 & 77.54 & 78.66 \\
\cline { 2 - 6 } & False & 32 & 21.9 & & \\
\cline { 2 - 6 } & Total & 146 & 100.0 & & \\
\hline
\end{tabular}

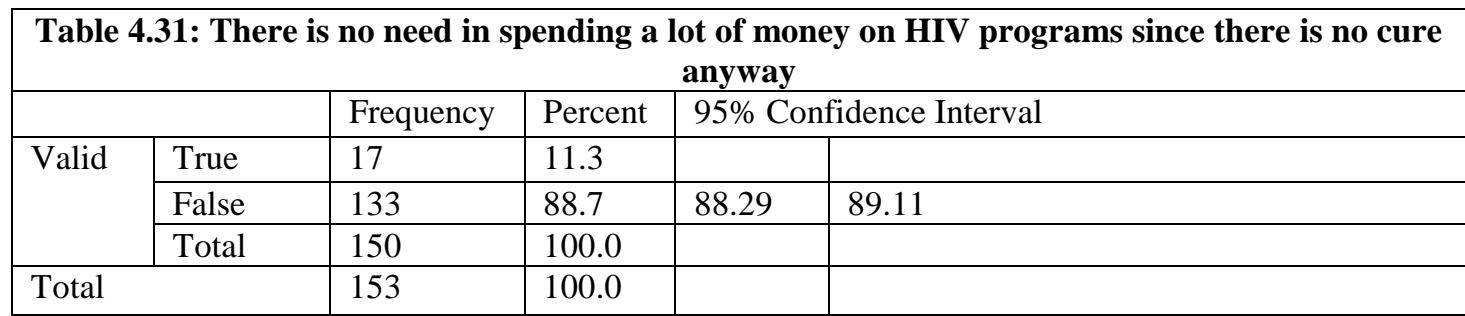

On the issue of concordant couples, $85.7 \%$ of the respondents rated the statement that there is no need for a concordant couple to use protection since they both have the virus. This is in line with the facts on the ground that protection against HIV virus should an ongoing exercise to give no chance to the virus, Table 4.32

\begin{tabular}{|c|c|c|c|c|c|}
\hline \multirow{4}{*}{ Valid } & \multirow[b]{2}{*}{ True } & \multirow{2}{*}{$\begin{array}{l}\text { Frequency } \\
21\end{array}$} & \multirow{2}{*}{$\begin{array}{l}\text { Percent } \\
14.3\end{array}$} & \multicolumn{2}{|c|}{$95 \%$ Confidence Interval } \\
\hline & & & & & \\
\hline & False & 126 & 85.7 & 85.23 & 86.17 \\
\hline & Total & 147 & 100.0 & & \\
\hline
\end{tabular}

There was general agreement among the respondents that Alcohol and Drug Abuse, (ADA) is a predisposing factor in contraction of the HIV virus. $87.1 \%$ of the respondents rated this statement as "true", Table 4.33. This is line with the facts on the ground that ADA can interfere with an individual's ability to make choices and appropriate decisions 


\begin{tabular}{|c|l|l|l|l|l|}
\hline \multicolumn{6}{|c|}{ Table 4.33: Alcohol and Drug abuse is a predisposing factor in contracting HIV } \\
\hline \multicolumn{2}{|c|}{} & Frequency & Percent & $95 \%$ Confidence Interval \\
\hline \multirow{3}{*}{ Valid } & True & 128 & 87.1 & 86.65 & 87.55 \\
\cline { 2 - 6 } & False & 19 & 12.9 & & \\
\cline { 2 - 6 } & Total & 147 & 100.0 & & \\
\hline
\end{tabular}

Counseling and testing were also seen as appropriate ways or entry point to care and treatment of HIV infections. The high number, $(86.6 \%)$ of respondents who supported this view shows the level of awareness among the students on the need to seek counseling to fight against HIV virus. This calls for strengthening the ACU department in all universities and public services. Table 4.34. Similarly, the respondents are aware that donating blood cannot make one be infected with HIV virus. This confirmed through the observation in Table 4.35 where $67.6 \%$ rated the statement as false. Facts show that donating blood cannot really be a channel through which HIV virus is transmitted. Blood transfusion also goes through a process of screening which minimizes chances of spreading the HIV virus

\begin{tabular}{|l|l|l|l|l|l|}
\hline \multicolumn{6}{|c|}{ Table 4.34: Counseling and Testing for HIV is an entry point to care and treatment } \\
\hline \multicolumn{3}{|c|}{} & Frequency & Percent (\%) & $95 \%$ Confidence Interval \\
\hline \multirow{3}{*}{ Valid } & True & 129 & 86.6 & 86.15 & 87.05 \\
\cline { 2 - 6 } & False & 20 & 13.4 & & \\
\cline { 2 - 6 } & Total & 149 & 100.0 & & \\
\hline
\end{tabular}

\begin{tabular}{|l|l|l|l|l|l|}
\hline \multicolumn{6}{|c|}{ Table 4.35: Donating blood can make one be infected with HIV } \\
\hline \multicolumn{3}{|c|}{} & Frequency & Percent (\%) & $95 \%$ Confidence Interval \\
\hline Valid & True & 48 & 32.4 & & \\
\cline { 2 - 6 } & False & 100 & 67.6 & 66.98 & 68.22 \\
\cline { 2 - 6 } & Total & 148 & 100.0 & & \\
\hline
\end{tabular}

The respondents were presented with various practices related to sexual encounters. There was high score, $(92 \%)$ for solo masturbation, (Table 4.36). This practice was seen as low risk practice as it does not involve any exchange of fluids or contact with a partner. Solo masturbation was followed by unprotected sex at $4.4 \%$ and $3.6 \%$ for homosexuality. These results implied that the respondents were aware of the risks involved in any sexual practices that involve two individuals.

\begin{tabular}{|l|l|l|l|l|l|}
\hline \multicolumn{9}{|c|}{ Table 4.36: Which of the following is a low risk in HIV infection } \\
\hline \multirow{3}{*}{ Valid } & Homosexuality & 5 & Prequency & Percent (\%) & $95 \%$ Confidence Interval \\
\cline { 2 - 6 } & Solo masturbation & 126 & 3.6 & & \\
\cline { 2 - 6 } & Unprotected anal sex & 6 & 92.0 & 91.61 & 92.39 \\
\cline { 2 - 6 } & Total & 137 & 4.4 & & \\
\hline
\end{tabular}

In terms of groups at risk, there was no general agreement for one particular group. The highest figures, (47.7\%) were for the statement that all the groups, truck drivers, IDUs, University students, fish mongers are at risk groups in relation to HIV infection - Table 4.37.

\begin{tabular}{|l|l|l|l|l|l|}
\hline \multicolumn{6}{|c|}{ Table 4.37: Which group is at less risk } \\
\hline \multirow{7}{*}{ Valid } & Frequency & Percent (\%) & $95 \%$ Confidence Interval \\
\cline { 2 - 7 } & Truck drivers & 10 & 7.7 & & \\
\cline { 2 - 6 } & IDU's & 25 & 19.2 & & \\
\cline { 2 - 6 } & $\begin{array}{l}\text { University } \\
\text { students }\end{array}$ & 6 & 4.6 & & \\
\cline { 2 - 7 } & Fish Mongers & 27 & 20.8 & & \\
\cline { 2 - 6 } & All the above & 62 & 47.7 & & \\
\cline { 2 - 6 } & Total & 130 & 100.0 & & \\
\hline
\end{tabular}

The statement that disclosure of HIV results should be kept open so that we can avoid those infected also generated mixed reactions among the respondents. Among the respondents $57.8 \%$ strongly disagreed with 
this statement and $19.7 \%$ disagreed. This confirms that HIV/AIDS related stigma still exists and more work should be done in this area, Table 4.38

\begin{tabular}{|l|l|l|l|l|l|}
\hline \multicolumn{6}{|c|}{ Table 4.38: HIV results should be kept open so that we can avoid those infected } \\
\hline \multirow{4}{*}{ Valid } & Frequency & Percent $(\%)$ & $95 \%$ Confidence Interval \\
\cline { 2 - 6 } & Strongly Disagree & 85 & 57.8 & 57.14 & 58.46 \\
\cline { 2 - 6 } & Disagree & 29 & 19.7 & & \\
\cline { 2 - 6 } & Agree & 19 & 12.9 & & \\
\cline { 2 - 6 } & Strongly Agree & 14 & 9.5 & & \\
\cline { 2 - 6 } & Total & 147 & 100.0 & & \\
\hline
\end{tabular}

Chi-square tests were carried out to find out whether there was any association between gender and the responses. On the use of condoms for instance, there were $62.13 \%$ of those who responded were males while $37.87 \%$ were females. $57.81 \%$ of the male respondents and $56.41 \%$ of the female respondents said that they used condoms all the time. These proportions were however not significant (Chi-square statistic $=1.284$, $p$ value $=0.733$ ). Current health stated was associated with gender (Chi square statistic $=59.969 \mathrm{p}$-value $=0.000$.

\begin{tabular}{|c|c|c|c|}
\hline \multicolumn{4}{|l|}{ Chi-Square Tests } \\
\hline & Value & Df & Asymp. Sig. (2-sided) \\
\hline Pearson Chi-Square & $1.284^{\mathrm{a}}$ & 3 & .733 \\
\hline Likelihood Ratio & 1.287 & 3 & .732 \\
\hline Linear-by-Linear Association & .163 & 1 & .686 \\
\hline $\mathrm{N}$ of Valid Cases & 103 & & \\
\hline
\end{tabular}

\begin{tabular}{|c|c|c|c|}
\hline \multicolumn{4}{|l|}{ Chi-Square Tests } \\
\hline & Value & $\mathrm{df}$ & $\begin{array}{l}\text { Asy } \\
\text { mp. Sig. (2-sided) }\end{array}$ \\
\hline Pearson Chi-Square & $59.969^{\mathrm{a}}$ & 7 & .000 \\
\hline Likelihood Ratio & 70.834 & 7 & .000 \\
\hline Linear-by-Linear Association & 46.948 & 1 & .000 \\
\hline $\mathrm{N}$ of Valid Cases & 100 & & \\
\hline
\end{tabular}

\section{DISCUSSIONS}

Even though knowledge level of students on HIV and AIDS is high, the varied response shows that the age bracket under study as reported (HIV Surveillance Report, UNAIDS Report 2015, UNICEF Report 2015, KAIS 2012) confirmed that the adolescents and the young adults are a vulnerable group under HIV threat. This study is one of the responses to other suggested youth friendly prevention mechanisms suggested by other researchers such as the adaptation of Adolescents and youth Assessment and Decision Making Tool (AADM) (UNICEF, 2015 Annual Report). This study contributes to the rapid monitoring of HIV knowledge level, attitude, prevalence and trends among the youth. The results from this study pointed out clearly the obvious sexual engagements among the youths. HIV knowledge level was high at $90 \%$ with positive attitude level at $76 \%$ but even though, the trends in sexual engagements results points out active sexual knowledge and sex type of activities as follows; heterosexual $(90 \%)$, oral sex $(6.6 \%)$ and anal sex $(2.67 \%)$, condom use $(57.3 \%)$, $7 \%$ alcoholics addicts, $7 \%$ had been raped, $1 \%$ were HIV positives. This result implies that further researches need to focus on best strategies which can guide the young adults to responsible adulthood.

Further implications of these results are that $76 \%$ are positively aware of the HIV scourge and they take responsibility for their actions in risky sexual engagements. On the contrary, only $31.5 \%$ of the young people have accurate basic knowledge of HIV transmission. In addition, despite their high knowledge level in HIV pandemic in general, this situation explains some of the reasons for the high increase rate of HIV prevalence among the youth. In Africa alone, about 2100 young adults and adolescences are infected with HIV every day (AVERT, 2016). Student's life styles in institutions of higher learning shows heightened increased puberty realization, peer pressure, risky sexual behaviours and sudden realization from parental freedom. The implications of this study is that it strengthens other studies such as Kenya county report on unintended pregnancies in Kenya (2014) which revealed that about $14 \%$ of pregnancies in Kenya often end in abortion. Since about $50 \%$ of responded who were pregnant consented to not willing to carry the pregnancy to term, It has been revealed that most of these abortions are performed by unskilled people, often in conditions that do not 
meet minimal medical standards and are not followed with the appropriate post-abortion care. These unsafe abortions result in about 2,600 deaths of women and girls annually in Kenya (Wamwana, E.B., Ndavi P.M, Gichangi P.B, Karanja J.g., Muia E.G. (2006).Further to this, if the study results revealed that $5.6 \%$ had multiple sexual partners while $28.9 \%$ engage in unprotected sex and $93.3 \%$ are in heterosexual relationships, then we may not rule out possibilities of risky sexual behaviours engagements since $13 \%$ do not even know the use of condoms. It has been observed and documented that, among female young adults and adolescence age groups, maternal mortality is one of the top cause of death worldwide (Olukoya, A.A., et al. 2001) especially in developing countries among women of reproductive age of whom the group under this study fell. Hence there is need to strengthen rigorous mentorship and guidance programmes in institutions of higher learning to help facilitate transition of young adults from childhood stages of development. Further studies may look into knowledge, perception and attitude in health system information herb for quick accessibility and utilization of health data and further research.

\section{REFERENCES}

[1] HIV Surveillance (2014) Annual Report

[2] HIV/AIDS AVERTS Reports (2015)

[3] Idele, P., et al (2014) 'Epidemiology of HIV and AIDS Among Adolescents: Current Status, Inequities, and Data Gaps

[4] Kenya AIDS Indicator Survey -KAIS, (2012)

[5] Krejcie at al (2002) R.V., \& Morgan, D. W. (1970) Determining sample size for research activities, Educational and psychological measurement, 30, 607-610.

[6] Mumah, J, Kabiru, CW, Mukiira, C, Brinton, J, Mutua, M, Izugbara, C,

[7] Birungi, H. and Askew, I. (2014). "Unintended Pregnancies in Kenya: A Country Profile," STEP UP Research Report Nairobi: African Population and Health Research Center.

[8] Olukoya, A.A., et al. (2001). Unsafe abortion in adolescents. Special Communication from the World Health Organisation. International Journal of Gynaecology and Obstetrics75(2): 137—147.

[9] UNAIDS (2014) The Gap Report

[10] UNICEF (2015) Annual Report

[11] Wamwana, E.B., Ndavi P.M, Gichangi P.B, Karanja J.g., Muia E.G. (2006): Socio-demographic characteristics of patients admitted with gynaecological emergency conditions at the Provincial General Hospital Kakamega 